Volume 13 Number 4, October-December 2019: pp. 321-332.

Copyright (c) 2019 FIAT JUSTISIA. Faculty of Law, Lampung

University, Bandarlampung, Lampung, Indonesia. ISSN:

1978-5186 | e-ISSN:2477-6238. Open Access:

http://jurnal.fh.unila.ac.id/index.php/fiat

Fiat Justisia is licensed under a Creative Commons Attribution 4.0 International License, which permits unrestricted use, distribution, and reproduction in any medium, provided the original work is properly cited.

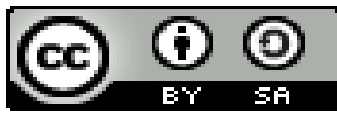

\title{
The Implementation of Chemical Castration Penalties towards Paedophilia Crime Perpetrators
}

\author{
Kartono \\ Universitas Pamulang, Indonesia \\ mohkart@gmail.com
}

Aji Mulyana

Universitas Suryakancana, Indonesia

ajimulyana94@gmail.com

\begin{abstract}
Sexual crime (rape) is one of the crimes that are very disturbing to the community, and its development is increasingly diverse either in the motives, nature, the form, the intensity and the modus operandi. The concerning situation is that a castration or castration law is expected to encouraging perpetrators of child sexual violence to lose their desire to repeat their crime. This research will explain how the implementation of chemical castration against sexual offenders on children (paedophilia) and how the application of castration penalties after the purpose of Indonesian crimes. The implementation of the imposition of the chemical castration sentence seems to be considered as an answer to the high public demand for severe punishment for the perpetrators. The existing rules of criminal law and child protection have never been implemented optimally. The Act of sexual assault on a child brings harmful impacts against physical and psychology to the victim, which became an obstacle for law enforcement officers to know or detect victims of sexual violence against children.
\end{abstract}

Keywords: Implementation, Crime, Pedophilia, Sex.

How to Cite: Kartono, Aji Mulyana, "Based on the Application of Chemical Castration Penalties against Perpetrators of Violence (Pedophilia)", Fiat Justisia, 13 (4), (2019).

DOI: 10.25041/fiatjustisia.v13no4.1683 


\section{A. Introduction}

Sexual crime is an Extraordinary Crime which is certainly a common problem and is a moral disaster that is difficult to cure. Sexual crimes often occur and cause deep concern for the future of children who are victims of these crimes. The impact of sexual crime will damage the young generation of the nation. Based on Act No. 23 of the year 2002 on the protection of the child, which explains that in Article 1 paragraph (2): Child protection is all activities to ensure and protect children and his rights in order to live, grow, evolve, and participate optimally in accordance with the dignity and the dignity of humanity, as well as the protection from violence and discrimination.

The perpetrators of sexual violence in children are usually adults whose scope is close to the victim, both the family environment and the people in the child's environment. Actors, in this case, are often referred to as paedophilia. The meaning of the word paedophilia is actually loved for children. However, there is a development of sense, so it is generally used as a term to describe one psychosexual disorder in which individuals have abnormal erotic desires towards children. ${ }^{1}$

Sexual crime (rape) is one of the crimes that are very disturbing to the community, and its development is increasingly diverse both the motives, nature, the form, the intensity and the modus operandi. As a social reality, the problem of criminality is unavoidable and indeed always exists, causing unrest because crime is considered a disruption to the welfare of the community and its environment.

The emergence of Government Regulation in Lieu of Law Number 1 of 2016 concerning the Second Amendment to Law Number 23 of 2002 concerning Child Protection, this Law went into an amendment of Law Number 17 Year 2016 dated November 9, 2016 regulating penalties for perpetrators of sexual crimes against children, namely the death penalty, for life, and a maximum of 20 years in prison and additional penalties in the form of announcing the identity of the perpetrator. Furthermore, the perpetrators can also be subjected to acts of chemical castration and installation of electronic detectors (See, Article 81 Section 7). ${ }^{2}$

The existence of additional penalties in the form of sterilisation or castration law is expected that the perpetrators of child sexual violence lose their desire to do their deeds again. The discourse did get community support, but some people refused the castration penalty. The imposition of additional sanctions in the form of castration criminality for perpetrators of sexual crimes against children (paedophilia) reaps many pros and cons. It is clear that the

\footnotetext{
${ }^{1}$ Sawitri Suparti Sadarjoen, Bunga Rampai Kasus Gangguan Psikoseksual, Bandung; Refika Aditama, (2005), p. 71.

${ }^{2}$ Republic of Indonesia State Gazette Year 2016 Number 99, Supplement to Republic of Indonesia State Gazette Number 5882.
} 
law plays a vital role in society and even has a multifunction for the good of society to achieve legal goals. ${ }^{3}$

Based on the background above, a problem arises in which the author needs to examine whether the application of punitive castration following with the intention of criminalisation Indonesian? And how barriers to the application of chemical castration (chemical castration) against the perpetrator of the criminal offence of sexual violence on children (paedophilia)?

\section{B. Research Methods}

The method used in this study is normative legal research that analyses the application of the law based on legislation that applies to experiences that occur in the community, as well as in the law enforcement process. This normative legal research uses a statutory approach, as well as a case approach. ${ }^{4}$

\section{Discussions}

\section{The Implementation of Chemical Castration Penalties towards Pedophilia Crime Perpetrators as a form of Criminalization}

Violence and sexual harassment have increasingly diverse patterns and motives. Victims that arise are not only adults who are considered to have the maturity of behaviour and way of thinking, but even adolescents under age or more directed towards children also are not spared being subjected to this psychological deviation. As the times and the world of technology are speedy, these activities become more modern and comfortable to get for the actors. One form is pornography to children through websites.

The term violence against children (child abuse) began to be known from the world of medicine in 1946. Damage is usually translated as violence, abuse, torture, or mistreatment, improper behaviour that results in physical, psychological, or financial harm or harm, both experienced individual or group. Child abuse is a physical and emotional repetitive act of damage to a child through insistence on desire, uncontrolled body punishment, degradation, and permanent ridicule or sexual violence and neglect so that the child loses the opportunity to develop his unique potential as a human being optimal. There are four types of violence against children, namely physical abuse, sexual violence, emotional violence, and negligence. Exploitation of children or employing minors for commercial purposes by overriding children's physical, mental and social development is another type of violence

\footnotetext{
${ }^{3}$ Adam Yuriswanto, Ahmad Mahyani, "Hukuman Kebiri Sebagai Pidana Tambahan Dalam Tindak Pidana Kejahatan Seksual”, DIH: Jurnal Ilmu Hukum, 14 (27), (2018), p. 30.

${ }^{4}$ Peter Mahmud Marzuki, Penelitian Hukum Edisi Revisi, Jakarta, Kencana Prenada Media Group, (2014), pp. 133-136.
} 
against children. ${ }^{5}$

Paedophilia is described as an adult human who has deviant sexual behaviour towards children. The word paedophilia itself comes from Greek, "blackheads" (children) and "philia" (love). ${ }^{6}$ The abnormality experienced is an intense and repetitive sex drive against the fantasies of pre-teenage children as a sex aberration and also a fatal legal violation. ${ }^{7}$

There are several types of paedophilia, as follows:

1. Fixated Type Pedophilia, namely someone who is only interested in small children, and has no interest in adults;

2. Non-Exclusive Type Paedophilia (regressed) that is someone who is not only interested in young children but also adults;

3. Cross-Sex Paedophilia is a man who likes to touch girls sexually. Generally the offender becomes a friend of the girl, and the opportunity gradually involves the child in sexual relations, and his nature is not compelling;

4. Same-Sex Paedophilia is someone who prefers to engage in sexual activity with same-sex children, and they do not have sexual relationships with adults of the opposite sex;

5. Men mostly do female Pedophilia, however, women can also suffer from paedophilia, although this is rarely reported. It may be due to the nature of maternal women with boys who do not regard this as something negative, so cases of female paedophiles are rarely reported. ${ }^{8}$

Paedophiles are people who have an adult sexual attraction to children and are targeted by prepubertal children (boys or girls who have not experienced puberty). ${ }^{9}$

Among the cases, many paedophiles have families as one form of camouflage that is done to cover up their psychosexual disorders. By utilising the innocence of children, paedophile offenders approach their victims by being good friends or companions for children, and even most paedophiles work in a school or other area that involves children to be closer to potential victims. Besides, additional efforts to satisfy sexual arousal are to persuade children or victims with things that can attract attention so that they want to

\footnotetext{
${ }^{5}$ Ratih Probosiwi dan Daud Bahransyaf, "Pedofilia Dan Kekerasan Seksual: Masalah Dan Perlindungan Terhadap Anak", Sosio Informa, 1 (1), (2015), p. 31.

${ }^{6}$ Vicky KhoilaWinarto, "Kebijakan Kriminalisasi Terhadap Pelaku Tindak Pidana Pedofilia Menurut Hukum Pidana Indonesia", JOM Fakultas Hukum, 3 (2), (2016), p. 9.

${ }^{7}$ Ahmad Sandi, "Hukuman Kebiri Bagi Pelaku Pedofilia Dalam Perspektif Hukum Islam dan Peluang Penerapannya di Indonesia", Skripsi Fakultas Syariah dan Hukum UIN Jakarta, (2015), p. 2.

${ }^{8}$ Vicky KhoilaWinarto, Loc Cit, p. 9.

${ }^{9}$ Ismantoro Dwi Yuwono, Penerapan Hukum dalam Kasus Kekerasan Seksual terhadap Anak, (Yogyakarta: Pustaka Yustisia, 2015), p. 44. Dikutip juga oleh Trini Handayani, "Peningkatan Ketahanan Keluarga melalui Optimalisasi Pola Asuh Maternalistik dalam Pencegahan Kejadian Pedofilia”, Padjadjaran Journal of Law, 3 (3), (2017), p. 551.
} 
obey what is desired by the perpetrators, even if paedophile sufferers often force with threats to minors to get sexual pleasure. ${ }^{10}$ Many paedophiles also exhibit narcissistic, sociopathic, and antisocial personality traits. They show fewer feelings of remorse and understand the dangers of their actions.

The regulation of paedophilia is not specifically regulated in Indonesian laws and regulations. During this time to ensnare the perpetrators, one of them is to use the provisions contained in the Criminal Code, namely Article 290 and Article 292 of the Criminal Code: "Adults who commit an act of violation of decency with an immature child of the same sex, who before his maturity he knows or deserves to be expected, is punished with imprisonment for a period of five years".

Then with the enactment of Law No. 23 Concerning Child Protection is one step to protect children, especially in relation to paedophilia, because in the law, it generally guarantees the fulfilment of children's rights to grow, develop and participate optimally by dignity and to obtain protection from violence.

Sexual violence against children can be seen from a biological and social point of view, which is interrelated with one another by having a psychological impact on children, which perpetrators commit sexual violence against underage children (before puberty), by damaging the child's vital organs. ${ }^{11}$

In terms of violence or threats of violence, according to M.H. Tirtaamidjaja, every action carried out with intended violence are mostly combined with body strength. Article 89 of the Criminal Code extends the notion of "violence" that is making people become unconscious or helpless, equated with committing violence. ${ }^{12}$

The impact of sexual violence has a traumatic effect on victims of sexual violence against children or adults. Victims of sexual violence, especially children, find it difficult to disclose because they do not understand that they are victims of fear when reporting because they feel threatened and are afraid to embarrass the family. ${ }^{13}$ Other impacts of sexual violence are Depression; Phobias; Nightmares; Always be suspicious of others; Alone; and suicidal. ${ }^{14}$

Along with the times, the Indonesian Criminal Code rules in giving sanctions (punishments) cannot provide a deterrent effect, so there are still many children who are victims of sexual violence. Therefore the legislators

\footnotetext{
${ }^{10}$ Mohammad Asmawi, Lika-Liku Seks Menyimpang Bagaimana Solusinya, Yogyakarta: Darussalam Offset, (2005), p. 93.

${ }^{11}$ Ivo Noviana, "Kekerasan Seksual Terhadap Anak: Dampak dan Penanganannya", Sosio Informa, 1 (1), 2015), p. 17. Dikutip juga oleh Trini Handayani, Op.Cit, p. 552.

${ }^{12}$ Leden Marpaung, Kejahatan Terhadap Kesusilaan, Jakarta: Sinar Grafika, (1996), p. 52.

${ }_{13}$ Trini Handayani, Op.Cit, pp. 558-559.

14 M. Anwar Fuadi, "Dinamika Psikologi Kekerasan Seksual: Studi Fenomenologi, Psikoislamika", Jurnal Psikologi Islam (JPI), 8 (2, (2011), p. 194.
} 
make a special rule that serves to protect children against the violence they experience both physical violence, psychological violence and sexual violence as stipulated in Article 81 and Article 82 of Law 17/2016. This legislation is a formulation of the Criminal Code which in this case provides criminal sanctions (punishments) against perpetrators who are more aggravated than the rules stipulated in the Criminal Code, namely the death penalty, lifetime, and a maximum of 20 years in prison and additional criminal announcement the perpetrator.

Furthermore, the perpetrators can also be subjected to acts of chemical castration and installation of electronic detectors. ${ }^{15}$

Two kinds of castration are applied in various countries, namely physical castration and chemical castration. Physical castration, as applied in the Czech Republic and Germany, is carried out by amputating paedophile testicles, which causes the perpetrators of testosterone deficiency to affect their sexual drive. While the chemical castration, unlike physical castration, is not done by amputating the testis. The executor will include anti-androgen chemicals that can weaken testosterone. The method can be through pills or injections. When the testosterone hormone is weakened, the erectile ability, libido, or one's sexual desire will decrease even disappear altogether. ${ }^{16}$

The effect of this chemical castration does not last permanently. If the administration of fluids is stopped, libido and erectile ability will function again. Some types of drugs that are widely used are medroxyprogesterone acetate (MPA) and cyproterone acetate (CPA).${ }^{17}$ The effect of this drug is in the range of 40 hours to 3 months. Several factors influence sexual drive or sexual arousal. One of the most important factors is the hormone testosterone.

Government Regulation instead of Law Number 1 of 2016 Concerning the Second Amendment to Law Number 23 of 2002 Concerning Child Protection which has been stipulated as Law Number 17 of 2016. The Law is made as a preventive measure to overcome and suppress crime increasing sexual impact on children, causing the soul and growth of children to be threatened. The provision of deterrent effects carried out through castration rehabilitation will be the primary goal in controlling and controlling the crime of paedophilia. ${ }^{18}$

In Indonesia, the application of chemical castration is contained in Law 17/2016 Concerning the Establishment of Government Regulation instead of Law Number 1 the Year 2016 Concerning the Second Amendment to Law No. 23/2002 Concerning Child Protection which was passed into law on November 9, 2016. The changes made in Law No. 17/2016, described in the

15 Nuzul Qur'aini Mardiya, "Penerapan Hukuman Kebiri Kimia Bagi Pelaku Kekerasan Seksual”, Jurnal Konstitusi, 14, (1), (2017), p. 216.

${ }^{16}$ Ibid.

${ }^{17}$ Ibid., p.219.

${ }^{18}$ Adam Yuriswanto, Ahmad Mahyani, Loc.Cit. 
provisions of Article 81, Article 82, 83 and Article, as well as control the Government Regulation in Lieu of Law Number 1 of 2016 concerning the Second Amendment to Law Number 23 of 2002 concerning Child Protection which has been stipulated as Law Number 17 of 2016, is a pressure from the public towards the government considering that sexual crimes against children have increased very rapidly every year.

According to Soerjono Soekanto "society can influence law enforcement in formulating and establishing a new legal regulation based on existing and developing social norms". In addition to the participation of the community as a social group, the law also follows a change that occurs in the city. The application of additional penalties in the form of castration contained in Law Number 17 of 2016, according to Adam Yuriswanto and Ahmad Mahyani has several elements, namely:

a. The juridical part which describes that the regulation is formed to overcome existing problems by considering the sense of justice in the community.

b. The reflective element illustrates that the regulation is a view of life, awareness and legal ideals.

c. Sociological elements indicate that the regulation is made to meet the needs of the community in various situations and circumstances. ${ }^{19}$

Regarding the application of chemical castration in Law Number 17/2016, different opinions were expressed by medical personnel. According to the Chairman of the Andrology and Sexology Section of the Faculty of Medicine, Udayana University, Denpasar, WimpiePangkahila, ${ }^{20}$ in the modern era, castration is indeed no longer done by removing the testicles, but chemically. The process can be through the administration of pills or injections of anti-androgen hormones. Chemistry can damage chemically and even undermine organ function, namely diminishing muscle function, osteoporosis, reducing the number of red blood cells, and disrupting the functioning of other cognitive organs. According to him, so far no data support if the application of chemical castration can give a deterrent effect more than the real punishment.

The implementation of the castration penalty as contained in Law Number 17 of 2016 until now the procedures and technicalities in implementing an application for the castration process have not been regulated in various derivative regulations either through Government Regulations (Peraturan Pemerintah) or Ministerial Regulations (Peraturan Menteri). It results in the judge handling and deciding a case unable to carry out the law to the fullest.

\footnotetext{
${ }^{19} \mathrm{Ibid}$.

20 http://m.news.viva.co.id/news/read/783180-ahli-tidak-ada-data-kalau-kebiri-beri-efek-jerapemerkosa, accessed on March 9, 2019.
} 
The overthrow of criminal sanctions against the perpetrators of the criminal act, the essential element is in criminal law. According To Herbet L. Packer, the importance of criminal penalties for perpetrators of criminal acts, namely: (1) criminal sanctions is indispensable for the present or future;(2) criminal sanctions is a tool or a means, to keep and provide protection against threats; (3) criminal sanctions is the main guarantor when used sparingly, carefully and humanely, because criminal sanctions is a threat, when used arbitrarily and forcibly. ${ }^{21}$

Criminalization against the perpetrator of a criminal offence should remain attentive to the values contained in the Pancasila, and in accordance with the development of the people, so that the punishment meted out to the perpetrators of criminal acts committed by judges can give impact positive against the perpetrators, and give a sense of fear to the community impact when performing a criminal act. The verdict imposed upon the perpetrators of criminal acts of sexual violence have to go through the process of criminalisation which is by the law, as well as considering about a positive or negative impact for the perpetrator. ${ }^{22}$

According to Hubertus Kasan Hidayat, the implementation of castration in Indonesia is carried out against perpetrators of repeated pedophilia crimes by giving an injection of anti-androgen sterilization in the form of a liquid named MPA (Medroxy Progesterone Acetate) or better known as depo Provera which is given to the perpetrator after the principal has served a necessary sentence. Another purpose of the punishment is also to provide rehabilitation in the form of healing by fostering criminal behaviour so that their sexual activities can be controlled if they are later returned to the community.

Vedije Ratkoceri in his writings entitled "Chemical Castration as a security measure in the criminal legislation of the Republic of Macedonia" which quotes from Tullio that Chemical castration is one of the most effective and least restrictive ways to help treat child predators and keep children safe. ${ }^{23}$

Besides, from the Indonesian Doctors Association (IDI), he also stated his refusal to become the executor of the castration penalty for perpetrators of sexual crimes against children. It is according to IDI because the

\footnotetext{
${ }^{21}$ Suwarnatha, I. N. N. Tujuan Pemidanaan Sanksi Tindakan Kebiri Kimia Bagi Pelaku Kekerasan Seksual Terhadap Anak. In Seminar Nasional Hukum dan Ilmu Sosial, Vol. 2, (2019, February). pp. 06-12.

22 Ibid.

${ }^{23}$ Vedije Ratkoceri, "Chemical Castration as a security measure in the criminal legislation of the Republic of Macedonia", International Journal of Social Sciences and Education Research, 3 (2), (2017), pp. 356-360.
} 
implementation of castration penalties by doctors is considered to violate the Doctor's Oath and Indonesian Medical Ethics Code. ${ }^{24}$

The government needs to strengthen prevention efforts and provide penalties for perpetrators of repeated sexual violence crimes, prepare rules for implementing technical implementation of additional penalties for chemical castration, infrastructure, human resources both health workers and psychologists who assist perpetrators who will undergo chemical castration procedures, and the budget for carrying out chemical castration on an ongoing basis. Monitoring court decisions to oversee the implementation of chemical castration by coordinating between ministries that are responsible in the legal, social and health sectors so that the purpose of the sentence becomes appropriate, namely to prevent recurring crimes of sexual violence and to create a deterrent effect on the perpetrators.

The implementation of the castration penalty must be by the applicable procedures and procedures by paying attention to the human rights possessed by the perpetrator, and the sentence must bring benefits as the main objective of the results of the rehabilitation carried out. Law as a tool to regulate the community authorises law enforcement officials to implement and implement regulation in the form of guidance in which the guidance is carried out by the procedures and capabilities possessed by law enforcement institutions as stated in the law.

\section{Barriers on Implementing Chemical Castration Penalties towards Pedophilia Crime Perpetrators}

Sexual violence mainly occurs in the traumatic impacts tend to be so profound. However, cases of sexual violence are often not easily revealed the absence of recognition of sexual violence events happened. Especially sexual violence that occurs in children under age, because children victims of sexual violence do not understand that he became a victim. The victim will be hard to trust others so secretive about what has happened to him (embarrassed both on herself or embarrass a family). In addition, children are afraid to report what had occurred because the victims feel threatened will have experienced worse things in a report. The impact of sexual abuse that occurred in the presence of marked powerlessness, where victims feel helpless and tormented when uncovering the events of sexual harassment. ${ }^{25}$

Acts of sexual violence on children's physical and psychological impact brought to the victim. In psychology, children who are victims of sexual violence are experiencing stress, depression, deep soul, the existence of feelings of guilt and blame themselves, the fear of dealing with others, the

\footnotetext{
${ }^{24} \mathrm{http}: / / \mathrm{www}$. antaranews.com/berita/566611/wapres-menghormati-keputusan-idi-tolakeksekusi-kebiri?utm_source=related_news\&utm_ medium=related\&utm_campaign=news, accessed on March 9, 2019.

25 Noviana, Op.Cit.,p. 18.
} 
shadow incident in which children receive sexual violence, nightmares, insomnia, anxiety with things related to abuse including objects, smells, places, doctor visits, self-esteem issues, sexual dysfunction, chronic pain, addiction, suicidal desire, somatic complaints, and unwanted pregnancy. Also it appears the psychological disturbances such as posttraumatic stress disorder, anxiety, other mental disorders include personality and dissociative identity disorder, a tendency to recall the adverse event will occur in the adult, even the existence of physical injuries to the child. ${ }^{26}$

Physically, the victim experienced a decrease in appetite, sleeplessness, headaches, uncomfortable around the genitals, vagina or at risk of contracting sexually transmitted diseases, wounds on the body due to rape with violence, unwanted pregnancy and other. ${ }^{27}$

Besides, most children who experience sexual violence feel the criterion of psychological disorder called posttraumatic stress disorder (PTSD), with symptoms in the form of a recurring fear happens, anxiety is high, and emotions stiff after traumatic events. ${ }^{28}$

The impact occurs in sexual violence against children were divided into two, namely the impact of psychological and physical impact, which became an obstacle for law enforcement officers to know or detect victims of sexual violence against children.

\section{Conclusion}

The execution of the penalty of castration in Law No. 17 years 2016 to present Ordinances and technical implementation of a process of castration has not been arranged into a variety of derivative regulation whether through Government Regulation (Peraturan Pemerintah) as well as Ministerial Regulation (Peraturan Menteri). It resulted in the judge in the handle and broke a matter could not perform the Act with maximum.

The execution of the penalty of castration was performed must be by the Ordinance and the applicable procedures by observing the rights owned by the offender and the punishment should take the benefit as the primary goal of rehabilitation outcomes which do.

A chemical castration sentence in Indonesia is an ultimium remedium to address the perpetrators of sexual crimes. These additional criminal has been by the system of criminalisation in Indonesia who hold a combined theory of absolute theory that can pose a deterrent effect and the relative theory which gives the benefit of the sentence through the rehabilitation process.

The Law of sexual assault on a child brings harmful impacts against physical and psychology to the victim, which became an obstacle for law enforcement officers to know or detect victims of sexual violence against

\footnotetext{
${ }^{26}$ Ibid.

${ }^{27}$ Ibid.

${ }^{28}$ Ibid.
} 
children.

\section{Bibliography}

\section{A. Book}

Asmawi, Mohammad. (2005). Lika-Liku Seks Meyimpang Bagaimana Solusinya. Aceh: Darussalam Offset.

Marpaung, Leden. (1996). Kejahatan Terhadap Kesusilaan. Jakarta: Sinar Grafika.

Marzuki, Peter Mahmud. (2014). Penelitian Hukum Edisi Revisi. Jakarta: Kencana Prenada Media Group.

Sadarjoen, Sawitri Suparti. (2005). Bunga Rampai Kasus Gangguan Psikoseksual. Bandung: Refika Aditama.

Soekanto, Soerjono. (2007). Faktor-Faktor yang Mempengaruhi Penegakan Hukum. Jakarta: Rajawali Press.

Yuwono, Ismantoro Dwi. (2015). Penerapan Hukum dalam Kasus Kekerasan Seksual terhadap Anak. Yogyakarta: PustakaYustisia.

\section{B. Journal and Thesis}

Adam Yuriswanto, Ahmad Mahyani, "Hukuman Kebiri Sebagai Pidana Tambahan Dalam Tindak Pidana Kejahatan Seksual”, DIH: Jurnal Ilmu Hukum, 14 (27), (2018), pp. 133-136, https://doi.org/10.30996/dih.v0i0.1592.

Ahmad Sandi, "Hukuman Kebiri Bagi Pelaku Pedofilia Dalam Perspektif Hukum Islam dan Peluang Penerapannya di Indonesia”, Thesis of Faculty of Sharia and Law of UIN Jakarta, (2015), p. 2.

Ivo Noviana, "Kekerasan Seksual Terhadap Anak: Dampak dan Penangannya", Sosio Informa, 1 (1), (2015), p. 552.

M. Anwar Fuadi, "Dinamika Psikologi Kekerasan Seksual: Studi Fenomenologi, Psikoislamika”, Jurnal Psikologi Islam (JPI), 8 (2), (2011), p. 194, https://doi.org/10.18860/psi.v0i0.1553.

Nuzul Qur'aini Mardiya, "Penerapan Hukuman Kebiri Kimia Bagi Pelaku Kekerasan Seksual", Jurnal Konstitusi, 14 (1), (2017), p. 216, https://doi.org/10.31078/jk14110.

Ratih Probosiwi dan Daud Bahransyaf, "Pedofilia dan Kekerasan Seksual: Masalah dan Perlindungan Terhadap Anak", Sosio Informa, 1 (1), (2015), p. 31.

Vedije Ratkoceri, "Chemical Castration as a Security Measure in the Criminal Legislation of the Republic of Macedonia", International Journal of Social Sciences and Education Research, 3 (2), (2017), pp. 356-360.

Trini Handayani, "Peningkatan Ketahanan Keluarga melalui Optimalisasi Pola Asuh Maternalistik dalam Pencegahan Kejadian Pedofilia”, 
Padjadjaran Journal of Law, 3 (3), (2017), pp. 558-559, https://doi.org/10.22304/pjih.v3.n3.a6.

Vicky Khoila Winarto, "Kebijakan Kriminalisasi Terhadap Pelaku Tindak Pidana Pedofilia Menurut Hukum Pidana Indonesia", JOM Fakultas Hukum, 3 (2), (2016), p. 2.

\section{World Wide Web}

http://m.news.viva.co.id/news/read/783180-ahli-tidak-ada-data-kalau-kebiriberi-efek-jera-pemerkosa

http://www.antaranews.com/berita/566611/wapres-menghormati-keputusanidi-tolak-eksekusi-kebiri?utm_source=related_news\&utm_ medium=related\&utm_campaign=news

Hubertus KasanHidayat, comperensive text book of psychiatry, dikutipdarihttp://m.youtu-be.com/watch?v=ISUfaaeqWTY, accessed on October 20, 2018 at $19.00 \mathrm{GMT}$.

\section{Regulations}

Republic of Indonesia State Gazette Year 2016 Number 99, Supplement to Republic of Indonesia State Gazette Number 5882. 